consortia probably feel by now that a two consortia solution is the best they can hope for, although industrial reactions are complicated by the fact that the chairman of Atomic Power Constructions, Colonel Raby, himself favours the single authority.

The chairman of the IRC, Sir Frank Kearton, has now completed a preliminary sounding out of the industry, and his conclusions are being considered by the Ministry of Technology. The ministry says that the work is going ahead at full speed, but that it "can't circumvent red tape completely", which is a fine use of understatement. In the industry, the past month or so has seen a quieter, more reflective tonesome observers see this as evidence that the industry has got down to serious talking, after several months of jockeying and lobbying. If this is correct, it is a welcome development-the consortia cannot be held blameless for failing to sort out their own industry.

Because of the confusion, few people are now talking in terms of ideal solutions. Any solution that could be worked out would come as such a welcome change that the principles on which it should be based have tended to be lost. In one sense it is hard to understand the objections to the single design authority. Britain already has only one company making aircraft engines, and only one domestic company making computers, and the mergers which led to this situation were generally welcomed. The CEGB itself has not always made use of the competitive position; the contract for the Hinkley Point B station was negotiated with only one consortium, and the others were not invited to tender. But, as time passes, the chances of forming one authority seem to be fading. The danger is that a half-hearted solution might be worse than no solution at all, although in the short term it would be welcomed. The overriding need is to improve the competitive position of the industry overseas; despite an investment in civil nuclear development which by some accounts approaches $£ 1,000$ million, the British nuclear power industry has not exported a power station for ten years. It is not a record of which anybody can feel proud.

\section{Oceanographers Divided}

Hopes for an oceanographic complex based at Plymouth are sinking, probably for the third and final time, after a meeting last Friday. The Royal Navy at Plymouth and the Natural Environment Research Council concluded that the naval facilities at Plymouth would not be suitable for its Research Vessel Unit. Last April, Mrs Shirley Williams, Minister of State at the Department of Education and Science, stated that the NERC had decided to move the unit from Plymouth (see Nature, 218, 415; 1968) to Barry, but this decision is now being reconsidered and no new decision has been made.

The unit has been based in Plymouth, at the Millbay Dockyard, since its inception in 1965, but when the NERC decided to expand the work of the unit and increase the number of vessels, it began to look for larger facilities than Millbay was able to offer. At present, the unit consists of two vessels-the RRS
John Murray, a stern trawler used since March 1967 by various university departments and now more than four times oversubscribed with requests for research time, and the RRS Discovery of the National Institute of Oceanography-but a new research vessel has been ordered which will be used jointly by universities and by the Scottish Marine Biological Association at Oban. The unit is also proposing to build a larger vessel, capable of handling large geological survey equipment and a two-man submersible operating in water up to 100 fathoms, for use by universities and the Institute of Geological Sciences, which is planning a survey of the continental shelf. Within the next ten years the NERC plans to have a fleet of five or six boats and all the scientific equipment necessary to meet the needs of these vessels.

The original decision to move to Barry drew loud protests from the Plymouth City Council and from Dr David Owen, MP for Plymouth Sutton, who claimed that the decision was made without consulting Plymouth or the various bodies concerned, such as the Oceanographic and Fisheries Commission of the NERC. The NERC decided to reconsider the site, but Mr C. J. Bridger of the NERC claims this is only because the Ministry of Transport has informed them that the port of Barry may not have a very long life if the recommendations of the National Port Council are put into effect; the council, set up to study the coordination of ports in Great Britain, concluded in 1965 that the port at Barry should eventually be closed and trade moved to Cardiff. While Barry had offered the unit more than adequate facilities-1,000 feet of quay space and six acres of adjacent land for storage and office buildings - the long-term prospects of the port should have been determined before the NERC announced its decision.

The Plymouth City Council and Dr Owen are anxious the unit should remain in Plymouth, because they feel that its presence, coupled with that of the Marine Biological Association, will help attract other oceanographic institutions. Dr Owen points out that in addition to the Marine Biological Association, Plymouth already has the Royal Naval Engineering complex and will soon have a polytechnic. He feels strongly that the Government should do all in its power to concentrate its scientific resources and to integrate the facilities of the research councils with other government departments, but claims that the NERC has made no attempt to keep the unit in Plymouth.

$\mathrm{Mr}$ Bridger states that there is little practical reason for the unit to remain in Plymouth as the Marine Biological Association alone is not large or important enough at present to warrant making Plymouth the site of an oceanographic complex. He admits that the presence of the unit would do much to attract other bodies, but says that while the NERC was willing for nostalgic reasons to remain at Plymouth if it were feasible, a port on the Severn estuary would be more practical, being closer to the major universities using the unit's vessels-London, Cambridge, Birmingham, Bristol, Bath, Liverpool, Durham and Aberystwythand close to an airport, an asset for researchers in Scotland.

Any argument about Plymouth at the moment seems to be academic, however, in spite of hopes that the Nary would be able to arrange adequate facilities for the unit at its Devonport Dockyard in Plymouth. 
After a meeting last Friday, June 7 , between Mr D. $J$. Maclean, Deputy Secretary (Scientific) of the NERC, and the admiral in charge of the Devonport Dockyard, the NERC has concluded that the dockyard will be unsuitable. The Navy would not be able to offer the unit civilian facilities at a naval dockyard. While berth space could be arranged, the Navy could not guarantee permanent berths and could not give land for equipment storage next to the vessels. Without these conditions, the NERC does not consider the Devonport Docks to be a viable solution and is now planning to look for a new site on the Severn if it is unable to change the decision of the Ministry of Transport to close the Barry docks.

\section{Poisoned Mussels}

INVESTIGATIONS are continuing into the cause of the poisoned mussels and of the death of hundreds of sea birds along the north-east coast of Britain. Everything points to a dinoflagellate "bloom" as the agent responsible, but so far it is proving difficult to track down and identify the specific organism producing the toxicity. It may possibly be a species of the dinoflagellate Gonyaulax but, so far, shore-line plankton samples along the Tyneside coast down as far as Hartlepool have proved negative. Samples are now being taken 4 miles off-shore and research vessels from the Ministry of Agriculture's Fisheries Laboratory at Lowestoft, and from the University of Newcastle, are helping in the operation. It is definitely all hands to the pumpsthere are now ten different groups of people concerned, and the main centres of activity are in Newcastle at the public health laboratory and at the university where Professor R. B. Clark of the Department of Zoology is leading operations. Work is also being done on the problem at the university's Dove Marine Laboratory at Cullercoats and at the University of Leeds Wellcome Marine Laboratory at Robin Hood's Bay. The birds are being investigated by Dr John Coulson of the Zoology Department, University of Durham.

Dinoflagellates are planktonic protozoa abundant in both marine and fresh waters. Sometimes they occur as blooms, becoming very abundant for a short time and then practically disappearing. Most species are harmless and form an important source of food for other organisms. A few species are, however, toxic and it is one of these that is suspected. Marine blooms of one reddish form produce "red tides" which occur along the Atlantic coast of the southern United States and kill fish in large numbers. These toxic "blooms" are not, however, confined to tropical and sub-tropical waters. They are found occasionally in the cold waters of the Bay of Fundy and in fjords in Norway, but are almost unknown in British waters. It is thought that the toxicity recorded in the north-east was caused by the normal spring bloom of a dinoflagellate "overbursting itself" as a result of a combination of a particular climatic condition and the right nutrients. It seems that the centre of the population explosion was around the Farne Islands. Indeed, one of the highest levels of natural toxicity ever recorded in the world was found on Holy Island.

The story first made news at the end of May, when some seventy cases of human enteritis were linked to poisoned mussels. None of the cases was very serious and the outbreak of poisoning was over quite quickly, as shellfish supplies were stopped and people were warned against eating any shellfish from the Northumberland coast. Since then, hundreds of shags (small cormorants) and other sea birds have been found dead on the Farne Islands and elsewhere on the Northumberland and Durham coast, and dead sand eels and flounders were washed up. The toxicity does not appear to be confined to the Farne Island district. There have been reports of it as far north as the Firth of Forth and south down to Bridlington. Officials from the Ministry of Agriculture and from the Department of Agriculture and Fisheries for Scotland are keeping a look-out all the way along the coast in case the toxicity is spreading further, and work is continuing to identify all the links in the food chains of the animals concerned.

\section{Australia Goes Metric?}

The United States and Canada may soon be the only two major countries still using the imperial system of weights and measures, if Australia follows the recommendations of a recent Senate committee report (Report from the Senate Select Committee on the Metric System of Weights and Measures, Parliament of the Commonwealth of Australia, 1968). The committee recommends that the use of imperial units be discontinued over a period of ten years and be replaced by the metric system, known as the International System of Units.

A major factor influencing the committee's decision was Australia's position in world trade: more than 90 per cent of the world's population is now living under a metric system and 75 per cent of the world's machine tools are produced in metric countries. Britain's decision to convert to the metric system by 1975 also influenced the committee. British industrial standards-on which Australia has always drawn heavily-will in future be metric, the future distribution of Australia's trade will be much more heavily loaded in favour of metric countries, and Britain's experiences in breaking new ground will be most helpful to Australia.

As evidence of the ease of conversion, the committee pointed to the fairly recent experiences of India and Japan. India, with relatively light industrialization, had little trouble teaching the new system even to illiterate villagers. Against this rural experience, Japan, highly industrialized and with a large international trade, began a positive programme of conversion in 1955 which was 85 per cent complete four years later. Evidence is that industry and commerce are pleased with the change, and major industries have claimed substantial savings in production costs following conversion.

If Australia does decide to convert, the United States will remain the outstanding country on the imperial system, but she is in many ways a unique case. While there have been many moves in Congress to initiate a study of the practicality of the metric system, none of these has yet been implemented. Many industries and technical publications already use the metric system, either exclusively or on a dual basis, but since more than 90 per cent of Amcrica's products are consumed internally, there is little outside pressure for total conversion. Also, the United States is already so heavily industrialized that the 